\title{
1323 衝撃のアクティブ制御の砕水船への応用
}

\section{Application of Active Shock Control to Icebreaker}

\author{
$\bigcirc$ 渡邉 圭 （千葉大），正 西村 秀和（慶應大） \\ 正 下鄉 太郎 （慶應大）
}

Kei WATANABE, Chiba University, 1-33, Yayoi-cho, Inage-ku, Chiba, 263-8522

Hidekazu NISHIMURA, Keio Univercity 2-15-45, Mita, Minato-ku, Tokyo, 108-8345

Taro SHIMOGO, Keio University, 3-14-1, Kohoku-ku, Yokohama, 233-8522

\begin{abstract}
This paper shows that the active hammer can reduce the deformation of the icebreaker by applying Active Control of Shock to the icebreaking process in the icebreaker. Although a usual icebreaker pushes the ice which has elastoplastic deformation characteristic to break ices by the breaker's hull, the icebreaker in this paper has the active hammer provided at the bow. The motion of active hammer is controlled by using two types of the triangular pulse, an acceleration pulse and a velocity pulse. For various peak positions and durations, the optimal command is searched to reduce deformation of the ice breaker by the numerical simulation. This paper shows not only the effective pulse shape of the active hammer, but also the difference of performance between steel and ice as the object to be plastically deformed.
\end{abstract}

Key Words: Active Control of Shock, Icebreaker, Active Hammer, pulse Input, Elastoplastic Deformation

\section{1. 緒言}

衝撃のアクティブ制御の先行研究として, 下郷ら ${ }^{(1)}$ は, 2 物 体間の衝突に関する問題を単純化するため, 2物体間の衝突部に アクチュエータを配置したモデルを用いて 1 自由度系モデルで 表した. そして, 最適制御理論による状態フィードバック制御 を行った. また，力の伝達の割合を 2 物体の変形比ととらえ，2 次形式評価関数に基づく最適レギュレータによる制御方法を適 用することで，変形比の最大化が可能となることを数值シミュ レーションにより示した. 王ら(2)(3) は同モデルに基づきアク ティブ衝撃制御の実証試験を行った。 そこではカルマンフィル 夕による状態推定に基づく LQI(Linear Quadratic Integral) 制 御と $H_{\infty}$ 制御, 終端状態制御をそれぞれ用い, 衝撃のアクティ ブ制御が実現可能であることを実証している.このような2物体 間の衝撃のアクティブ制御は鉎造機械や，削岩機，砕承船など へ応用できると考えられる。

現在, 北極海に埋蔵されているエネルギ一資源の輸入や水海 観測技術の発展のため等, いろいろな目的で砕水船の開発が行 われている. 北極海は一年中氷で团まれており, 大型の水塊も ある. その中を進む砕水船は, 水塊の抵抗で船体停止に至るこ とがある．このような場合には，船体を一度後退させ，再び前 進して, 推力をかけながら氷塊に激突する. その際, 最悪の場 合には沈船に至ることにもなり得る(4).

そこで本研究では, 下郷らのモデルと同様に衝突部にアクチュ エータを配置したモデルを用いてこれを砕水船に応用し，アク チュエータを搭載したアクティブハンマーを船首に取り付けた 力学モデルを作成する. そして, 砕水船が氷塊を砕氷する際の 船体と水塊の変形を能動的に制御する方法について検討する. また, 破壊する物体を鉄鋼材料的な弾塑性変形特性の物体とし たときの数值シミュレーションを行い, 水塊の場合との比較を 行う.

\section{2. アクティブハンマーを有する砕水船}

制御対象のモデルを Fig. 1に示し，その模式図をFig. 2に示 す. 衝撃を与える船体は, 質点 $m_{2}$ とばね $k_{3}$ で弾性結合された 質点 $m_{3}$ で構成され，アクチュエータを搭載したアクティブハ ンマ一を船首に取り付け, 水塊を破壊する.また, 船体と氷塊 との接触剛性は $k_{2}$ とする. 衝撃を受ける水塊は, 弾塑性変形特 性を有するため, $x_{1}=x_{0}$ で弾性変形領域から塑性変形領域へ

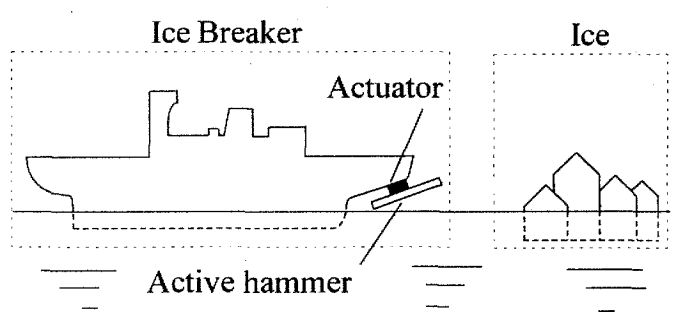

Fig. 1 Schematic diagram of icebreaker with active hummer and ice

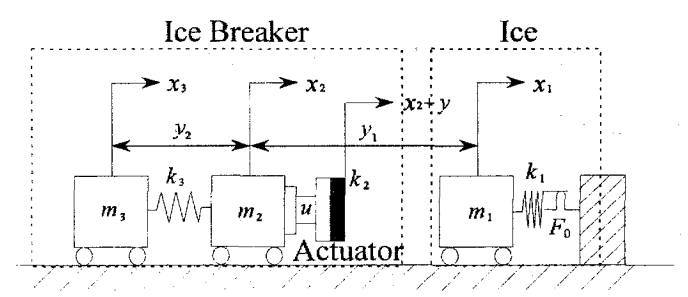

Fig. 2 Dynamical model of ice breaker and ice

遷移するものとして（Fig. 3），ばね定数 $k_{1}$ のばねとクーロン ダンパ $F_{0}$ で構成されるものとする.

Fig. 2に示した制御モデルの各パラメータをTable 1に示す。 この值は、文献 ${ }^{(5)}$ を参考にして与えられた。また、接触岡性 $k_{2}$ は、衝突時による船体の跳ね返りや接触部の変形量を考慮して 与えた。Fig. 2に示した制御モデルの運動方程式を導くと式 (1) となる.

$$
\begin{aligned}
& m_{1} \ddot{x}_{1}=-F+k_{2}\left(x_{2}-x_{1}+y\right) \\
& m_{2} \ddot{x}_{2}=-k_{2}\left(x_{2}-x_{1}+y\right)+k_{3}\left(x_{3}-x_{2}\right) \\
& m_{3} \ddot{x}_{3}=-k_{3}\left(x_{3}-x_{2}\right)
\end{aligned}
$$

ここで, $x_{1}, x_{2}, x_{3}$ は各質点の絶対変位, $y$ はアクチュエータ の変位を表し，速度パルスを積分して得られる変位である. 相 対変位 $y_{1}=x_{1}-x_{2} 、 y_{2}=x_{2}-x_{3}$ を用いると式(1)は次の

日本機械学会 [No.07-13] 第 10 回 [運動と振動の制御」シンポジウム講演論文集 [2007.8.9〜11・東京] 


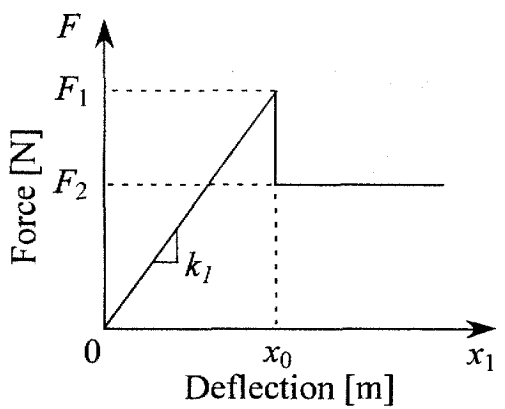

Fig. 3 Load-deflection characteristic of ice

\section{ように表される。}

$$
\begin{aligned}
& m_{1} \ddot{x}_{1}=-F-k_{2} y_{1}+k_{2} y \\
& m_{2}\left(\ddot{x}_{1}-\ddot{y}_{1}\right)=k_{2} y_{1}-k_{3} y_{2}-k_{2} y \\
& m_{3}\left(\ddot{x}_{1}-\ddot{y}_{1}-\ddot{y}_{2}\right)=k_{3} y_{2}
\end{aligned}
$$

氷塊の変形荷重特性は断片線形となるため式 $(2)$ の $F$ は，弾性 変形領域と塑性変形領域で次のとおりとなる.また，水塊の変 形荷重特性を Fig. 3に示す.

$$
F=\left\{\begin{array}{lr}
k_{1} x_{1} & \left(x_{1} \leq x_{0}\right) \\
F_{2} & \left(x_{1}>x_{0}\right)
\end{array}\right.
$$

シミュレーションの解析結果の汎用性を持たせるために，運 動方程式の無次元化を行うと, 式(2)は式(4) となる.

$$
\begin{aligned}
& \frac{\mathrm{d}^{2} \xi_{1}}{\mathrm{~d} \tau^{2}}=-\frac{F}{F_{1}}-\Omega_{2}^{2} \mu_{2} \eta_{1}+\Omega_{2}^{2} \mu_{2} \eta \\
& \frac{\mathrm{d}^{2} \eta_{1}}{\mathrm{~d} \tau^{2}}=-\frac{F}{F_{1}}-\Omega_{2}^{2}\left(1+\mu_{2}\right) \eta_{1}+\Omega_{3}^{2} \frac{\mu_{3}}{\mu_{2}} \eta_{2}+\Omega_{2}^{2}\left(1+\mu_{2}\right) \eta \\
& \frac{\mathrm{d}^{2} \eta_{2}}{\mathrm{~d} \tau^{2}}=\Omega_{2}^{2} \eta_{1}-\Omega_{3}^{2}\left(1+\frac{\mu_{3}}{\mu_{2}}\right) \eta_{2}-\Omega_{2}^{2} \eta
\end{aligned}
$$

無次元化を行う上での基本量, 無次元量は以下のように定義 する.

- 基本量

長さ: $x_{0}($ :氷塊の降伏点変形量 $)$

時間: $1 / \omega_{1}\left(\omega_{1}\right.$ :水塊の弾性領域固有角振動数 $)$

質量: $m_{1}$ (:水塊の質量)

- 無次元量

変位: $\xi_{1}=x_{1} / x_{0}, \xi_{2}=x_{2} / x_{0}, \xi_{3}=x_{3} / x_{0}$

入力: $\eta=y / x_{0}$

時間: $\tau=\omega_{1} t$

振動数比: $\Omega_{2}=\omega_{2} / \omega_{1}, \Omega_{3}=\omega_{3} / \omega_{1}$

質量比: $\mu_{2}=m_{2} / m_{1}, \mu_{3}=m_{3} / m_{1}$

Table 1 Parameters for simulation

\begin{tabular}{c|c||c|c}
\hline$m_{1}$ & $283.5 \times 10^{3} \mathrm{~kg}$ & $F_{1}$ & $150 \times 10^{6} \mathrm{~N}$ \\
\hline$m_{2}$ & $6500 \times 10^{3} \mathrm{~kg}$ & $F_{2}$ & $40 \times 10^{6} \mathrm{~N}$ \\
\hline$m_{3}$ & $6500 \times 10^{3} \mathrm{~kg}$ & $x_{0}$ & $0.3 \mathrm{~m}$ \\
\hline$k_{1}$ & $5.0 \times 10^{8} \mathrm{~N} / \mathrm{m}$ & & \\
\hline$k_{2}$ & $4.5 \times 10^{8} \mathrm{~N} / \mathrm{m}$ & & \\
\hline$k_{3}$ & $1.0 \times 10^{9} \mathrm{~N} / \mathrm{m}$ & & \\
\hline
\end{tabular}

ここで, 状態変数べクトルを式 (5) と定義して, 弾性変形領域 と塑性変形領域の状態方程式を導くと式 (6)のようになる.

$$
\begin{aligned}
& x=\left[\begin{array}{llllll}
\xi_{1} & \eta_{1} & \eta_{2} & \dot{\xi}_{1} & \dot{\eta}_{1} & \dot{\eta}_{2}
\end{array}\right]^{T} \\
& \dot{x}=A_{l} x+B \eta \quad\left(\xi_{1} \leq 1\right) \\
& \dot{x}=A_{n} x+B \eta+E_{n} \quad\left(\xi_{1}>1\right)
\end{aligned}
$$

$A_{l}$ は弾性変形領域のシステム行列, $A_{n}$ は塑性変形領域のシステ 厶行列, $B$ は制御入力の係数, $E_{n}$ は塑性変形領域におけるク一 ロンダンパを表す非線形行列であり, 以下のように表される.

$$
\begin{aligned}
& A_{l}=\left[\begin{array}{cc}
0_{3 \times 3} & I_{3 \times 3} \\
A_{l 21} & 0_{3 \times 3}
\end{array}\right] \\
& A_{n}=\left[\begin{array}{ll}
0_{3 \times 3} & I_{3 \times 3} \\
A_{n 21} & 0_{3 \times 3}
\end{array}\right] \\
& A_{i 21}=\left[\begin{array}{ccc}
-1 & -\Omega_{2}^{2} \mu_{2} & 0 \\
-1 & -\Omega_{2}^{2}\left(1+\mu_{2}\right) & \frac{\mu_{3}}{\mu_{2}} \Omega_{3}^{2} \\
0 & -\Omega_{2}^{2} & -\Omega_{3}^{2}\left(1+\frac{\mu_{3}}{\mu_{2}}\right)
\end{array}\right] \\
& A_{n 21}=\left[\begin{array}{ccc}
0 & -\Omega_{2}^{2} \mu_{2} & 0 \\
0 & -\Omega_{2}^{2}\left(1+\mu_{2}\right) & \frac{\mu_{3}}{\mu_{2}} \Omega_{3}^{2} \\
0 & -\Omega_{2}^{2} & -\Omega_{3}^{2}\left(1+\frac{\mu_{3}}{\mu_{2}}\right)
\end{array}\right] \\
& B=\left[\begin{array}{llllll}
0 & 0 & 0 & \Omega_{2}^{2} \mu_{2} & \Omega_{2}^{2}\left(1+\mu_{2}\right) & -\Omega_{2}^{2}
\end{array}\right]^{T} \\
& E_{n}=\left[\begin{array}{llllll}
0 & 0 & 0 & \frac{F_{2}}{F_{1}} & \frac{F_{2}}{F_{1}} & 0
\end{array}\right]^{T}
\end{aligned}
$$

\section{3. 速度パルスによるシミュレーション}

3.1 パルス形 本章では, 砕水船が氷塊に衝突すること を想定した場合のシミュレーションを行った. なお, シミュレー ションソフトとしてMATLABを用いて，アクチュエータの入 カにFig. 4に示す速度パルスを与えた.このとき, サンプリン グタイムは $0.003 \mathrm{~s}$ とした. また, 承塊の変形荷重特性より, 水 塊の破壊後の船体に対する荷重は, 破壊前の荷重と比べて非常 に小さいため, 破壊後の水塊の変形量は検討せずに船体の変形 量のみを検討する. $t_{m}$ は三角波パルスのピーク時刻を， $t_{0}$ はパ

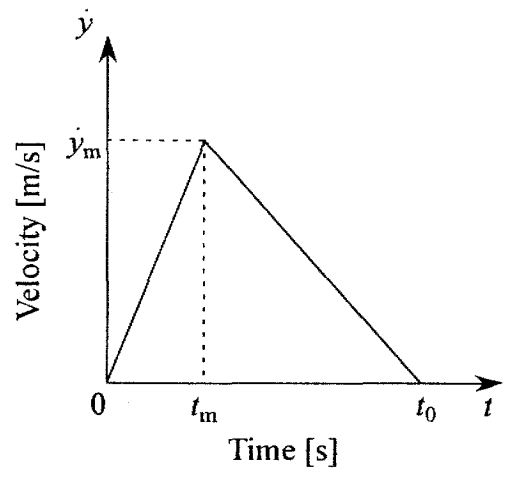

Fig. 4 Velocity pulse for simulation 
ルスの作用時間を示す，入力には速度パルスを積分したものを 用いるものとし, 無次元化した入力の式を式 (7)に示す。 また, $t_{m}, t_{0}, \dot{y}_{m}$ を無次元化すると, それぞれ $\tau_{m}, \tau_{0}, \dot{\eta}_{m}$ となる.

$$
\begin{aligned}
& \eta=\frac{\dot{\eta}_{m}}{2 \tau_{m}} \tau^{2} \quad\left(0 \leq \tau<\tau_{m}\right) \\
& \eta=-\frac{\dot{\eta}_{m}}{2 \tau_{\tau}} \tau^{2}+\frac{\dot{\eta}_{m} \tau_{0}}{\tau_{l}} \tau+B \quad\left(\tau_{m} \leq \tau<\tau_{0}\right) \\
& \eta=\frac{\dot{\eta}_{m} \tau_{0}^{2}}{2 \tau_{l}}+B \quad\left(\tau_{0} \leq \tau\right) \\
& \tau_{l}=\tau_{0}-\tau_{m} \\
& B=\frac{\dot{\eta}_{m} \tau_{0}^{2}}{2 \tau_{l}}
\end{aligned}
$$

以降のシミュレーションでは，この速度パルスの面積を一定と するため, アクティブハンマーの終端ストローク量が一定とな る.また, 船体には衝突前に初速度のみを与えるものとし, 衝 突後に推力を与えないものとする.

3.2 アクチュエータの有用性 アクチュエータの有用性 を検証するために，アクチュエータへ入力を与えた場合と，入 力を与えずに船体の初速度のみで氷塊を破壊する場合（非制御 時）とのシミュレーションの比較を行う．このシミュレーショ ン結果をFig. 5 に示す. 非制御時の船体の初速度は, $2.6 \mathrm{~m} / \mathrm{s}$ とし，これは非制御時に氷塊が降伏に至る最小の初速度である. また，制御入力を与えた場合の船体の初速度は， $2.0 \mathrm{~m} / \mathrm{s}$ とし， この初速度のみでは氷塊は降伏に至らない，点線，実線はそれ ぞれ非制御時とアクチュエータに速度パルス入力を与えた場合 の結果である. ピーク時刻とパルス作用時間は，それぞれ $t_{m}=$ $0.2 t_{0}, t_{0}=0.06 \mathrm{~s}$ とした.

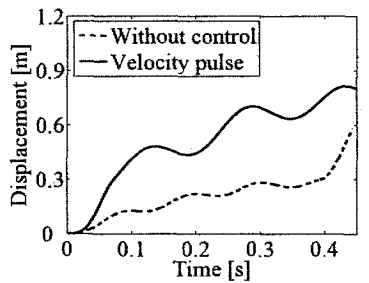

(a) $x_{1}$

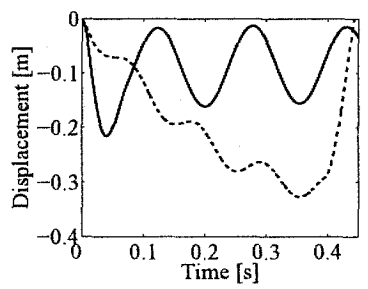

(c) $y_{1}-y$

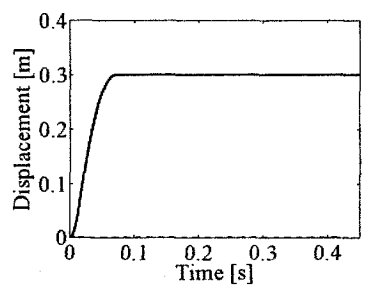

(e) $y$

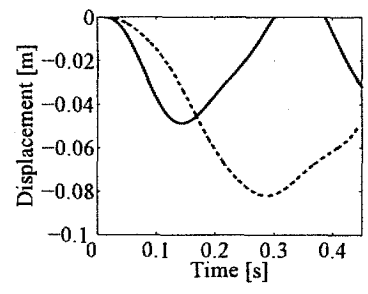

(b) $y_{2}$

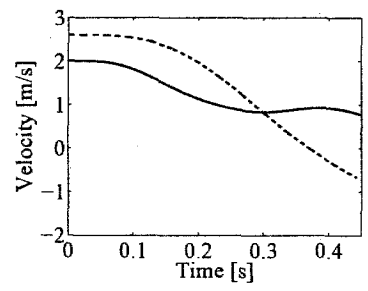

(d) $\dot{x}_{2}$

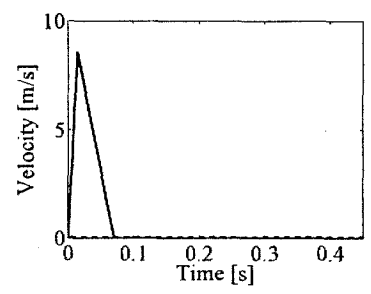

(f) $\dot{y}$

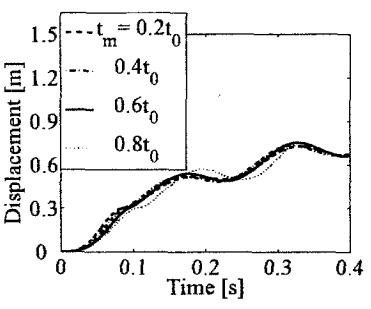

(a) $x_{1}$

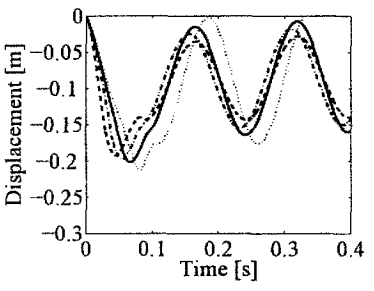

(c) $y_{1}-y$

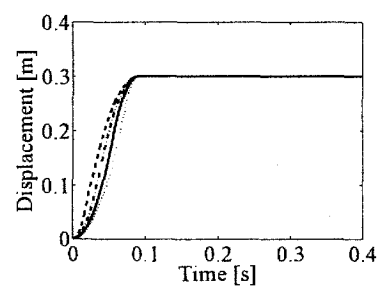

(e) $y$

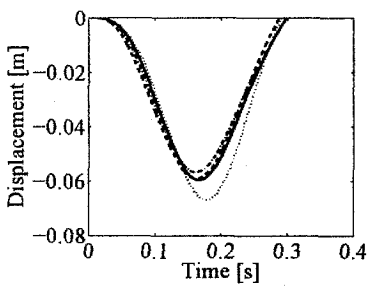

(b) $y_{2}$

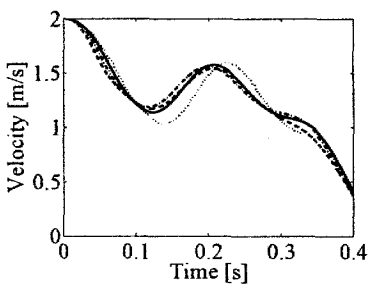

(d) $\dot{x}_{2}$

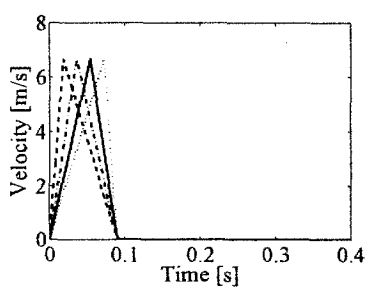

(f) $\dot{y}$
Fig. 5 Time history responses of velocity pulse and without control

Fig. 6 Time history responses by changing $t_{m}$ of velocity pulse for a beginning speed of $2 \mathrm{~m} / \mathrm{s}$ 
(a) より, $t_{m}=0.2 t_{0}, 0.4 t_{0}, 0.6 t_{0}, 0.8 t_{0}$ の場合とも承塊の 変形量が降伏点 $0.3 \mathrm{~m}$ を超えて降伏していることがわかる. (b) より, ピーク時刻 $t_{m}=0.2 t_{0}, 0.4 t_{0}, 0.6 t_{0}$ の場合，船体の最 大変形量に差はないが, ピーク時刻 $t_{m}=0.8 t_{0}$ の場合, 船体の 最大変形量が $t_{m}=0.2 t_{0}, 0.4 t_{0}, 0.6 t_{0}$ の場合よりも大きいこと がわかる. (c)より，ピーク時刻 $t_{m}$ を遅く与えるほどゆるやか に接触部の変形は進むが, 接触部の最大変形量は大きいことが わかる. (d) より水塊が降伏した後も前進していることがわか る. (e), (f)より, アクティブハンマーの終端ストローク量が一 定であることがわかる.

したがって, ピーク時刻 $t_{m}$ を早めに与え, アクティブハン マーの速度のピークを早めに与えると, 接触部の最大変形量が 抑えられ, 船体の最大変形量も抑えられる.

3.4 パルス作用時間による比較 船体に初速度 $2 \mathrm{~m} / \mathrm{s}$ を 与え, パルス作用時間 $t_{0}$ を変化させるシミュレーションを行っ た.ここで, ピーク時刻は $t_{m}=0.2 t_{0}$, アクチュエータのスト ローク量は, $0.3 \mathrm{~m}$ とし，このシミュレーション結果を Fig. 7 に示す. 鎖線, 一点鎖線, 実線, 点線は, パルス入力時間を $t_{0}$ $=0.06,0.07,0.08,0.09 \mathrm{~s}$ とした場合の結果である.

(a)より, $t_{0}=0.06,0.07,0.08,0.09 \mathrm{~s}$ の場合とも水塊の変 形量が降伏点 $0.3 \mathrm{~m}$ を超えて降伏していることがわかる. (b)よ り，パルス作用時間 $t_{0}$ を短く与えるほど船体の最大変形量が小 さく抑えられていることがわかる. (c)より, パルス作用時間 $t_{0}$ を短く与えるほど接触部の変形は早く進み, 接触部の最大変形 量も大きいことがわかる. (d)より氷塊が降伏した後も前進し ていることがわかる. (e), (f) より, アクティブハンマーの終端 ストローク量が一定であることがわかる.

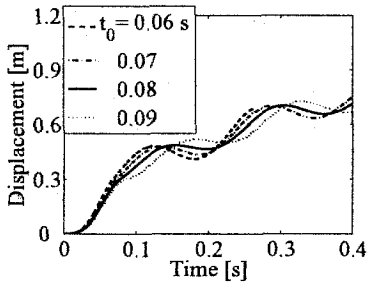

(a) $x_{1}$

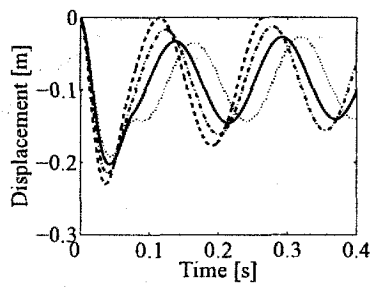

(c) $y_{1}-y$

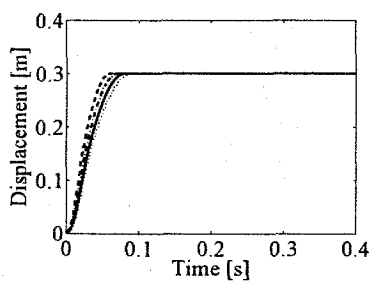

(e) $y$

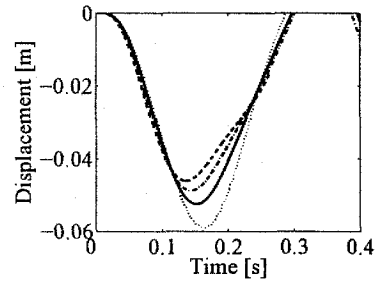

(b) $y_{2}$

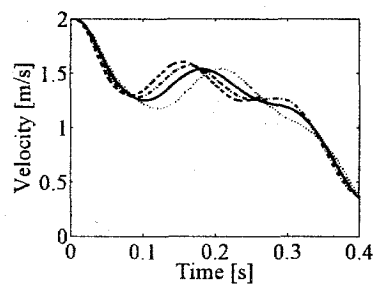

(d) $\dot{x}_{2}$

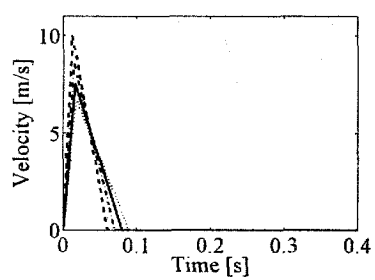

(f) $\dot{y}$
Fig. 7 Time history responses by changing $t_{0}(=0.06 \sim 0.09$ s) of velocity pulse
したがって，パルス作用時間 $t_{0}$ を短く与えるほど，接触部の 最大変形量は大きくなるが, 船体の最大変形量は抑えられるこ とができる.

3.5 考察 水塊のように降伏後に塑性変形の抵抗による 相当質量が減少するような物体に対しては, 速度パルスのピー クは早く与えたほうが反力が小さくなって船体の最大変形量は 小さくなる，衝撃に関与した相当質量と速度パルスとの積，す なわち力積 (運動量) パルスは, Diracのデルタ関数として最 初に与えることによって衝撃力を大きくすることができる. 力 積の変化をゆるやかにすれば, 衝撃力が小さくなるだけである. パルス作用時間を短くすると反力が大きくなるが，反力のピー クがみられる時刻は, 船体の最大変形量がみられる時刻よりも 十分に早いため, 船体の最大変形量が大きくなることはない. また, 反力のピークを早めに与え, 氷塊を早く破壊し, その後 は船体の慣性によって衝突させたほうが船体の変形量が小さく なる。

\section{4. 鉄鋼材料を塑性変形させる場合との比較}

前章までは，破壊する物体を水塊としてシミュレーションを 行ってきたが, 本章では破壊する物体が鉄鋼材料の弾塑性変形 特性を有するものとする，そして，船体が水塊に衝突した場合 との比較を行う. Fig. 8 に代表的な鉄鋼材料の変形荷重特性を 示す.また, 弾性変形領域と塑性変形領域の荷重 $F$ は, 次のと おりとなる. パラメータ $k_{1}, F_{1}, x_{0}$ の值は氷瑰の場合と同様と する.

$$
F=\left\{\begin{array}{lc}
k_{1} x_{1} & \left(x_{1} \leq x_{0}\right) \\
F_{1} & \left(x_{1}>x_{0}\right)
\end{array}\right.
$$

このように，鉄鋼材料の変形荷重特性は氷塊のそれとは異なり， 塑性変形領域に遷移しても荷重は減少しない. したがって, 塑 性領域での変形量も検討する必要性がある，そこで，鉄鋼材料 的な対象物体の最大塑性変形量 $x_{1 \max }-x_{0}$ と船体の最大変形量 $\left|y_{2}\right|_{\text {max }}$ の比で定義された塑性変形率(1)を用いた.

$$
\text { deformation ratio }=\frac{x_{1 \max }-x_{0}}{\left|y_{2}\right|_{\max }}
$$

この塑性変形率が高いほうが対象物体を破壊するのに効率的と いえる.これを鍛造機械の問題におきかえると，ハンマーの先 端に制御棒を装着した場合に相当し, 上式は工作物の塑性変形 量とハンマーの弾性ひずみとの比に対応している.

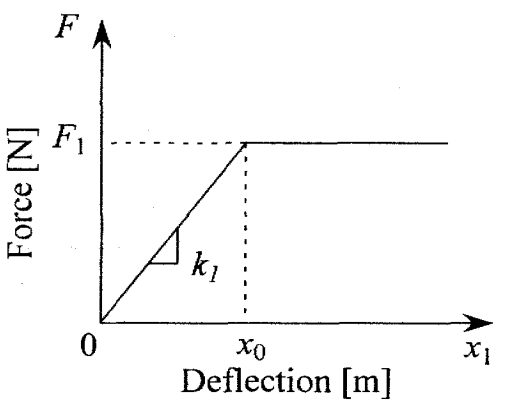

Fig. 8 Load-deflection characteristic of steel 
4.1 ピーク時刻による比較 船体に初速度 $2 \mathrm{~m} / \mathrm{s}$ を与 て，アクチュエータへの入力に速度パルスを用いてシミュレー ションを行った，パルス作用時間 $t_{0}$ を一定とし，ピ一ク時刻 $t_{m}$ を変化させた．ここで，パルス作用時間 $t_{0}$ は， $t_{0}=0.09 \mathrm{~s}, ア$

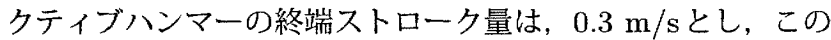
シュミレーション結果を Fig. 9 に示す. 鎖線, 一点鎖線, 実線, 点線は, ピーク時刻を $t_{m}=0.2 t_{0}, 0.4 t_{0}, 0.6 t_{0}, 0.8 t_{0}$ とした 場合の結果である.

(a) は物体の変形量, (b) は船体の変形量, (c) は接触部の変 形量，(d) は船体の速度，(e)はアクティブハンマーのストロー ク量, (f) はアクティブハンマーのストローク速度を示す.また, Table 2 に物体の最大塑性変形量 $x_{1 \max }-x_{0}$, 船体の最大変形 量 $\left|y_{2}\right|_{\text {max }}$, 塑性変形率を示す.

Fig. 9 (a), Table 2より, $t_{m}=0.2 t_{0}, 0.4 t_{0}, 0.6 t_{0}, 0.8 t_{0}$ の場合とも物体の変形量が降伏点 $0.3 \mathrm{~m}$ を超えて降伏している ことがわかる. また，ピーク時刻 $t_{m}$ を早めに与えるほど物体の 最大塑性変形量は大きいことがわかる. Fig. 9 (b), Table 2 よ り，ピーク時刻 $t_{m}$ を早めに与えるほど船体の最大変形量が抑え られることがわかる. (c)よりピーク時刻 $t_{m}$ を遅く与えるほど, 接触部の変形量の最初のピークが大きいことがわかる. (d) よ り船体は初速度 $2 \mathrm{~m} / \mathrm{s}$ で衝突し, 物体が降伏した後に後退して いることがわかる. (e), (f)よりアクティブハンマーの終端ス トローク量は一定であることがわかる.

Table 2 Shimulation results by changing $t_{m}$ of velocity pulse

\begin{tabular}{c||c|c|c|c}
\hline$t_{m}[s]$ & $0.2 t_{0}$ & $0.4 t_{0}$ & $0.6 t_{0}$ & $0.8 t_{0}$ \\
\hline$x_{1 \max }-x_{0}[\mathrm{~m}]$ & 0.0611 & 0.0652 & 0.0604 & 0.0480 \\
\hline$\left|y_{2}\right|_{\max }[\mathrm{m}]$ & 0.1073 & 0.1080 & 0.1098 & 0.1124 \\
\hline deformation ratio & 0.5692 & 0.6034 & 0.5504 & 0.4275 \\
\hline
\end{tabular}

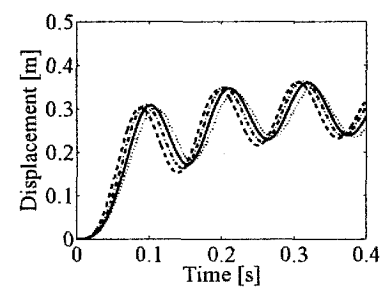

(a) $x_{1}$

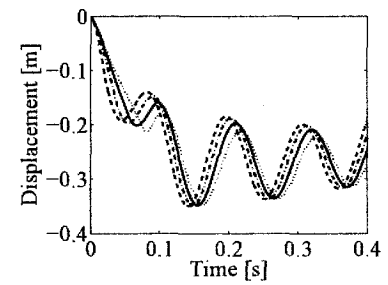

(c) $y_{1}-y$

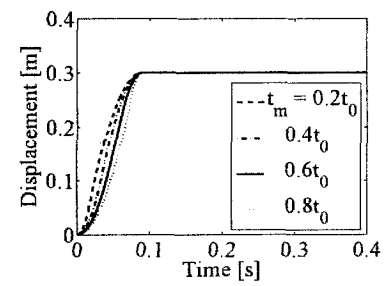

(e) $y$

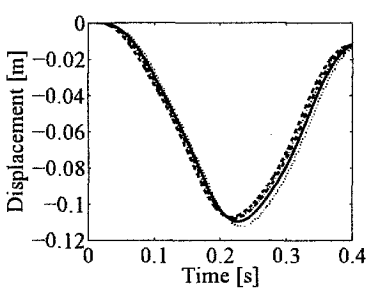

(b) $y_{2}$

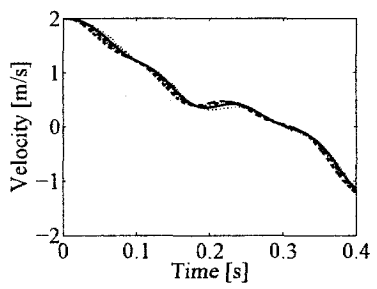

(d) $\dot{x}_{2}$

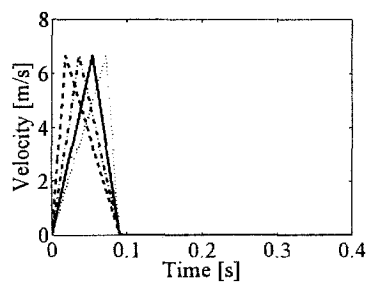

(f) $\dot{y}$
Fig. 9 Time history responses by changing $t_{m}$ of velocity pulse on steel
したがって, ピーク時刻 $t_{m}$ を早めに与えるほど船体の最大変 形量隹抑えられ, 物体の最大塑性変形量が大きい. また, Table 2 より, 塑性変形率はピーク時刻 $t_{m}$ を早めに与えるほど大きい.

4.2 パルス作用時間による比較 船体に初速度 $2 \mathrm{~m} / \mathrm{s}$ を 与え，パルス作用時間 $t_{0}$ を変化させるシミュレーションを行っ た. ここで, ピーク時刻は $t_{m}=0.2 t_{0}$, アクチュエータの終端 ストローク量は $0.3 \mathrm{~m}$ とし，このシミュレーション結果を Fig. 10 に示す. また, Table 3 に物体の最大塑性変形量 $x_{1 \text { max }}-x_{0}$ と船体の最大変形量 $\left|y_{2}\right|_{\text {max }}$, 塑性変形率を示す. 鎖線, 一点鎖 線, 実線, 点線は, パルス作用時間を $t_{0}=0.01,0.03,0.06$, $0.09 \mathrm{~s}$ とした場合の結果である.

Fig. 10 (a), Table 3 より, $t_{0}=0.01,0.03,0.06,0.09 \mathrm{~s}$ の 場合とも物体の変形量が降伏点 $0.3 \mathrm{~m}$ を超えて降伏しているこ とがわかる. また，パルス作用時間 $t_{0}$ を短く与えたほうが物体 の最大塑性変形量が大きいことがわかる. Fig. 10 (b), Table 3 より, パルス作用時間 $t_{0}$ を短く与えるほど船体の最大変形量が 抑えられていることがわかる. (c)より，パルス作用時間を短く 与えるほど接触部の変形は早く進み, 最初のピークが大きいこ とがわかる. (d)より船体は初速度 $2 \mathrm{~m} / \mathrm{s}$ で衝突し, 物体が降 伏した後に後退していることがわかる. (e), (f)よりアクティ ブハンマーの終端ストローク量は一定であることがわかる.

Table 3 Shimulation results by changing $t_{0}$ of velocity pulse

\begin{tabular}{c||c|c|c|c}
\hline$t_{0}[s]$ & 0.01 & 0.03 & 0.06 & 0.09 \\
\hline$x_{1 \max }-x_{0}[\mathrm{~m}]$ & 0.1213 & 0.1233 & 0.1007 & 0.0611 \\
\hline$\left|y_{2}\right| \max [\mathrm{m}]$ & 0.0925 & 0.0941 & 0.0998 & 0.1073 \\
\hline deformation ratio & 1.3113 & 1.3099 & 1.0091 & 0.5692 \\
\hline
\end{tabular}

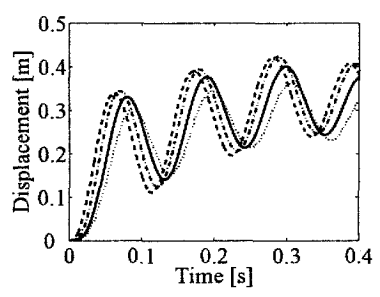

(a) $x_{1}$

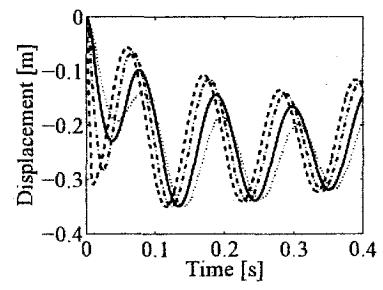

(c) $y_{1}-y$

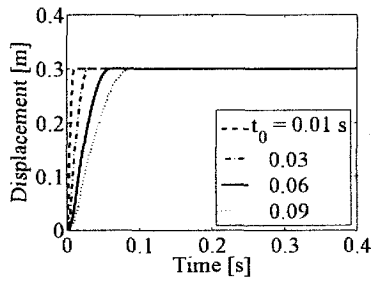

(e) $y$

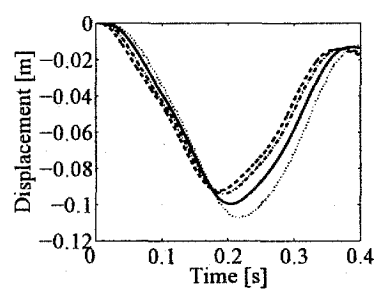

(b) $y_{2}$

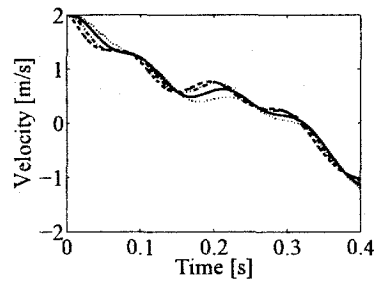

(d) $\dot{x}_{2}$

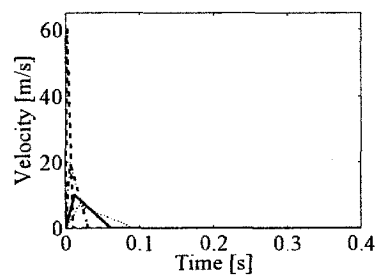

(f) $\dot{y}$
Fig. 10 Time history responses by changing $t_{0}$ of vlocity pulse on steel 
したがって，パルス作用時間 $t_{0}$ を短く与えるほど船体の最 大変形量が抑えられ, 物体の最大塑性変形量は大きい. また, Table 3 より, 塑性変形率はパルス作用時間 $t_{0}$ を短く与えるほ ど大きい.

4.3 考察 鉄鋼材料のように降伏後も塑性変形の抵抗に よる相当質量が維持されるような物体に対しては, 速度パルス のピークは早く与えたほうが反加小さくなって船体の最大変 形量は小さくなる，また，速度パルスによる衝撃では，材料の 特性の如何によらず，Diracのデルタ関数として最初に与える ことによって衝撃力を大きくすることができる，その際，反力 が大きくなるが, 反力のピークがみられる時刻は，船体の最大 変形量がみられる時刻よりも十分に早いため, 船体の最大変形 量が大きくなることはない. また, 衝撃パルスのピークを早め に与え, 対象物体を早く破壊し, その後は船体の慣性によって 衝突させたほうが船体の変形量が小さくなる.これを氷塊の場 合と比較すると，同様の傾向がみられたと考えられる．

\section{5. 結言}

本研究では, 䂗氷船が水塊に激突する際の船体への衝撃力を 緩和させるため, 船体の船首にアクチュエータを搭載したアク ティブハンマーを取り付けることを提案した. そして，その力 学モデルに基づいて数值シミュレーションを行った結果, アク チュエータの入力に速度パルスを用いて, そのピーク時刻，パ ルス作用時間を変化させることにより, 船体への衝撃力を緩和 するための条件を明らかにすることができた，また，衝突する 物体を鉄鋼材料とした場合のシミュレーションを行い，水塊と した場合との比較を行った. その結果, 水塊の場合と同様の傾 向がみられた.

\section{文 献}

（1）下郷，川島，住，衝撃制御に関する研究（一方向への衝 撃伝達），日本機械学会 D\&D2001 講演論文集，529.pdf， (2001)

(2) 王，西村，下郷，衝撃のアクティブ制御（LQI制御と $H_{\infty}$ 制御の適用)，日本機械学会論文集 (C 編), vol.71, No.704, pp.1223-1230, (2005)

（3）王，西村，下郷，天野，フィードフォワード入力による衝 撃のアクティブ制御, 日本機械学会論文集 (C 編), vol.71, No.710, pp.2912-2919, (2005)

（4）北川，小野, 泉山, 北極海航路, シップ・アンド・オーシャ ン財団, (2000)

（5）野澤, 氷海工学, 成山堂書店, (2006) 